\title{
Reading Ability and Reading Motivation of German Primary School Girls and Boys-The Teachers’ Perception
}

\author{
Martina Endepohls-Ulpe \\ University of Koblenz-Landau, Campus Koblenz, Koblenz, Germany
}

\begin{abstract}
Studies in the field of mathematics have shown that teachers have stereotyped attitudes towards girls' mathematical abilities, which have detrimental effects on girls' self-concepts and their achievement in this subject. Little is known so far about corresponding processes for boys' reading competencies. The presented study analyzes the assessment of gender differences in children's reading abilities and reading motivation by German primary school teachers. One hundred and seventy-two teachers filled in a questionnaire with several questions on reading competencies, reading behavior and reading interest of girls and boys. Differences between the appraisal of girls and boys and differences between the answers of male and female teachers were analyzed by analysis of variance. Results show that teachers assume significant gender differences in reading competencies, reading motivation, and reading behavior in favor of the girls. Interestingly, male teachers assess these differences even to be greater than female teachers do. As a consequence, it seems necessary to analyze and discuss the influences of these stereotyped perceptions on boys' reading self-concepts and reading motivation. Results are also discussed with respect to the "feminization of teaching" discourse.
\end{abstract}

Keywords: reading ability, gender differences, gender stereotypes, teachers, primary school children

\section{Introduction}

After decades of research on disadvantages for girls in the educational system, "male underachievement" has become a frequently discussed topic in the social sciences. Especially after the-at least for some countries, e.g., Germany- “shocking” results of the PISA (Programme for International Student Assessment) survey, boys' deficits in achievement got into the focus of attention. As a consequence also the media, as well as numerous publications in popular sciences identified boys as the so-called "new losers" in the educational system and their situation was labeled as "crisis" (for an overview see Hadjar, 2011; Hannover \& Kessels, 2011).

But looking at the statistical figures with respect to school grades and certificates and the results of the most important surveys on student assessment on boys' achievement in school, the resulting picture for Germany is not that uniform. As far as achievement at school in general is concerned, the so-called "boy problem" does not seem to be a new one. It had just been covered by keeping the girls back from higher levels of education up to the 1960s (Endepohls-Ulpe, 2011; Helbig, 2012).

In Germany, in the field of mathematics differences are still discovered in favor of the boys regularly. Whereas several studies reveal that girls and boys enter school with equal preconditions for learning 
mathematics (Tiedemann \& Faber, 1994, as cited in Budde, 2008; Rohe \& Quaiser-Pohl, 2010), an articulate gender gap already seems to develop in favor of the German boys in elementary school, and this gap is greater than in some other European countries. For older students, assessment studies like PISA and TIMSS (Trends in International Mathematics and Science Study) show better results for males and the differences to girls' results are greater than in other European countries as well (difference in PISA 2006: 19 points, as cited in Blossfeld et al., 2009).

Everywhere in Europe, and this is also the case in Germany, one of the most striking gender differences in achievement for older children and the most frequently discussed issue of concern in the context of "male underachievement" is the gender gap in reading achievement. This gap is revealed by all international assessment studies conducted in the last decade. Also in PIRLS (Progress in International Reading Literacy Study) 2006 girls in the fourth grade in average showed better reading achievement (Mullis, Martin, Kennedy, \& Foy, 2007). But there were also countries where no gender differences were found. In Germany, mean differences between reading competences of girls and boys were very small—only seven points, which makes the difference just significant (Bos et al., 2007). There are several other German studies with primary school children that do not detect any gender differences in reading at all or at least only very small differences (Herwartz-Emden, Braun, Heinze, Rudolph-Albert, \& Reiss, 2008; Kölbl, Tiedemann, \& Billmann-Mahecha, 2006). Actually, the gender gap in reading does not get really visible before we take a look at the reading achievement of older students. In PISA 2009, the mean difference in reading achievement between German girls and boys was 40 points in favor of the girls (Naumann, Artelt, Schneider, \& Stanat, 2010). Similar differences for 15-year-old students have been detected in all former PISA surveys. In Germany, the number of extremely poor readers is three times as high for the boys as for the girls (Naumann et al., 2010)

In spite of their poorer reading abilities, boys' self-concept with respect to this domain is as high as the one of the girls (Möller \& Bonerad, 2007). There seem to be differences in interest and engagement in reading activities that are crucial for their lower achievement (Naumann et al., 2010). These differences are found for 15-year-old students (Naumann et al., 2010) but can already be noticed for primary school children (Bos et al. 2007; Möller \& Bernard, 2007). For the group of boys and girls who are highly interested in reading activities no gender differences in reading achievement can be found (Prenzel et al., 2004).

There is also evidence that male and female students have different reading preferences with respect to certain text types or genres, but the results of studies concerning this matter are not quite consistent. Richter and Plath (2007) as well as Riedinger (2011) found out that primary school girls are significantly more motivated to read stories and books than their male peers. Richter and Plath (2007) found no gender differences concerning comics, magazines, or picture stories, whereas Riedinger (2011) showed that boys prefer comics, and books or stories on television series or films. Boys are looking for suspense and adventure, like to read about heroes and fights, whereas girls prefer stories about friendship or human fates, stories related to their own lives (see Philipp \& Garbe, 2007, p. 17) and stories about animals (Riedinger, 2011). A difference which is consistently found in studies on reading interest and reading motivation is that a greater number of girls use to read just for fun (see Riedinger, 2011).

There are several causes for gender differences in the educational system that are discussed in literature (for an overview see Endepohls-Ulpe, 2011; 2012). With respect to boys' inferior reading achievement interestingly congenital biological differences—having been used for decades to underpin the thesis of females' 
intellectual inferiority - are frequently mentioned as a cause in the last decade. Boys are said to have deficits in language development and the development of fine motor skills, which hinder their process of learning to read and to have different learning styles and different needs with respect to physical activity which schools do not take into account (Birkenbihl, 2005; for a discussion and critique see Gilbert, 2009). Up to now, there is little evidence for innate biological disadvantages detrimental to boys' reading competencies. Gender-specific processes of reading socialization seem to be more promising when looking for explanations for gender differences (Bos et al., 2007).

A second explanation especially for boys' difficulties at school is the so-called "feminization of teaching". In Germany as well as in most of the European countries, in the early years of schooling most of the teachers are female. This circumstance leads boys to define school as something feminine and to oppose against the requests of instruction (Rohrmann, 2007). There are even authors who postulate a discrimination of boys by their female teachers in primary school, e.g., by giving them worse marks or not recommending them for attending upper secondary school in spite of their sufficient aptitude (for an overview see Neugebauer, 2011). Against the thesis that female teachers have a negative impact on boys' achievement some empirical evidence has been collected during the last years (Hadjar, 2011). Boys in general do not do better at school when taught by male teachers nor do girls better when taught by females, but boys as well as girls show more positive attitudes towards school in general when they are instructed by females (Carrington, Tymms, \& Merrel, 2008). With respect to the field of reading boys' achievement is not necessarily higher in countries with a higher percentage of male primary school teachers (Blossfeld et al., 2009), and boys are not better in reading when their teachers are male. When taught by a female teacher they do not stereotype reading as a female activity (Sokal, Katz, Chaszeswski, \& Wojcik, 2007).

Gender stereotypes have an impact on the process of identity formation of children and thereby also on their achievement in certain domains. Children and adolescents tend to engage in activities which fit to their self-concept as a male or female. This is said to have the consequence that boys avoid activities which they stereotype as female, e.g., reading, working diligently, cooperating with teachers, etc. (Hannover, 2004). For girls, stereotypes are postulated to directly affect their performance in male connoted tasks by a phenomenon which is called "stereotype threat". When a task is marked as a male-typical one, this will have a negative effect on the achievement of females when performing this task (see Steele, 1997). This could be shown in experimental studies especially for mathematical and spatial tasks (e.g., Neuburger, Jansen, Heil, \& Quaiser-Pohl, 2012; Spencer, Steele, \& Quinn, 1999). It could also be shown that teachers have stereotyped beliefs about the abilities of male and female students. They think that girls' abilities in the field of STEM (science, technology, engineering, and mathematics) are lower than boys' and by expressing these gender-stereotyped beliefs about students' abilities they often create stereotype threat for girls in their classes (Rustemeyer \& Jubel, 1996; Tiedemann, 1995; Ziegler, Kuhn, \& Heller, 1998).

Up to the moment, only a few studies have examined the impact of stereotypes on boys' reading achievement (Eckert \& Imhof, 2011, 2012; Schirner, in press) and also little is known about teachers' beliefs about boys' reading abilities and reading motivation. Schirner (in press) identified a group of primary school teachers in her sample who indeed attributed inferior competences in the subject "German language" to boys.

Looking at the discussion of the "boy problem" in media, in popular science, and in education politics one could assume that there are indeed “... beliefs, shared by members of one group, about the shared 
characteristics of another group” (Wright \& Taylor, 2003, p. 433) in terms of teachers sharing negative attitudes against boys' reading abilities. Actually compared to reactions, e.g., in the UK, Australia, or the USA (see Lingard, 2003; Mills, 2003; Titus, 2004; Smith, 2003; Weaver-Hightower, 2003), German education policy on the whole, at least until 2010 (see Hannover \& Kessels, 2011; Neugebauer, 2011), in fact reacted rather unexcitedly in view of gender differences in achievement, trying to meet the needs of boys and girls (BfFSFJ (Bundesministerium für Familie, Senioren, Frauen und Jugend), 2007; Budde, 2008; Blossfeld et. al, 2009). However, in the last years numerous measures were initiated at German primary schools to improve the reading competencies of boys (Engelhardt, 2006), assuming that the origins of boys' lack of progress in reading achievement in secondary school must already lie in their primary school years and thus probably nurturing stereotypes about gender differences in reading for younger children.

\section{Issues and Conception of the Study}

\section{Aim of the Study}

The presented study analyzes German primary school teachers' attitudes with respect to gender differences in primary school children's reading abilities, reading behavior, interest, reading motivation, and possible gender-specific detrimental influences on their reading ability. As the "feminization of teaching" debate postulates a discrimination of boys by female teachers, e.g., by giving worse marks, differences between female and male teachers' attitudes are examined as well.

\section{Method}

As a measuring instrument a questionnaire was created, consisting of mostly closed-ended, 5-step-Likert items, and containing three parts:

(1) Reading competencies, reading behavior, reading interest, and influences on reading competencies of girls (33 items);

(2) Reading competences, reading behavior, reading interest, and influences on reading competencies of boys (33 items, parallel to items for girls);

(3) Text genres used by teachers for reading instruction in their own classes, personal data. Item examples:

(1) How do you assess the reading competencies of the girls (in average) with respect to: Reading fluently: 1 = "Very good", 2 = "Rather good", 3 = "Satisfactory", 4 = "Rather poor", 5 = "Poor".

(2) How do you assess the verbal abilities of the girls (in average) at the time they enter primary school? 1 = "Very good", 2 = "Rather good", 3 = "Satisfactory", 4 = "Rather poor", 5 = "Poor".

(3) How strong do the following factors influence girls' reading competencies? Parents who do not read: 1 = "Very strong”, 2 = "Strong”, 3 = "Weak", 4 = "Very weak", 5 = "Not at all”.

(4) Please complete the following statement: Girls read books to relax: 1= "Very often", 2 = "Often”, 3 = "From time to time", 4 = "Rarely", 5 = "Never".

\section{Statistical Analysis}

Differences between the appraisal of girls and boys and differences between the answers of male and female teachers were analyzed by $2 \times 2$ analysis of variance with repeated measurement, sex of teacher as fixed factor and assessment of boy or girl as repeated measurement. Gender differences on items concerning texts used in lessons were analyzed by two tailed $t$-tests. 
As a general appraisal of boys' and girls' reading competencies the mean score of the six items on different aspects of the reading competence was calculated for each teacher (index reading competency).

\section{Results}

\section{Sample}

The sample consisted of 172 German primary school teachers, mostly from schools situated in the federal state of Rhineland Palatinate, gender ratio: $88.2 \%$ female, $11.8 \%$ male (median of age: 38, min. 24, max. 64; mean of years of professional experience: 13).

This gender ratio of the teachers is almost representative for the whole population of primary school teachers in Germany (85.5\% female, 14.5\% male, academic year 2011/2012; Statistisches Bundesamt, 2012) The mean age of the sample is lower than that of the whole population of teachers in Germany (Statistisches Bundesamt, 2012). This is probably due to the fact that the collection of the data was done by two master students, who gathered some of the test persons in their acquaintanceship.

\section{Reading Competencies}

Regarding the mean values teachers assessed children's reading competencies to be between "Rather good" and "Satisfactory". The results of the $2 \times 2$ ANOVAs (analyses of variance) showed that teachers assessed girls' reading competencies in general to be significantly better than the boys', which was true for all detailed competencies—namely reading fluently, taking details from texts, looking up words, summarizing texts, structuring texts, and reproducing texts. Values of $\eta^{2}$ indicate large effect sizes ( 0.11 to 0.44 ; Bühner, 2011) (see Table 1).

Table 1

Assessment of Reading Competency

\begin{tabular}{|c|c|c|c|c|c|c|c|c|c|c|}
\hline Competency & $\begin{array}{l}M(S D) \\
\text { girls }\end{array}$ & $\begin{array}{l}M(S D) \\
\text { teachers }\end{array}$ & Female/Male & $\begin{array}{l}M(S D) \\
\text { boys }\end{array}$ & $\begin{array}{l}M(S D) \\
\text { teachers }\end{array}$ & Female/Male & $\begin{array}{l}F \quad \text { (Inner } \\
\text { subject } \\
\text { effect) }\end{array}$ & $\eta^{2}$ & $\begin{array}{l}F \\
\text { (Interaction } \\
\text { sex of child } \\
\times \text { Sex of } \\
\text { teacher) }\end{array}$ & $\eta^{2}$ \\
\hline $\begin{array}{l}\text { Reading } \\
\text { fluently }\end{array}$ & $2.12^{1}(0.41)$ & $2.14(0.41)$ & $2.00(0.32)$ & $2.82(0.53)$ & $2.79(0.51)$ & $3.05(0.60)$ & $133.97^{* * *}$ & 0.44 & $7.68^{* *}$ & 0.04 \\
\hline $\begin{array}{l}\text { Taking } \\
\text { details from } \\
\text { texts }\end{array}$ & $2.33(0.54)$ & $2.34(0.54)$ & $2.25(0.55)$ & $2.80(0.58)$ & $2.77(0.55)$ & $3.00(0.79)$ & $53.26^{* * *}$ & 0.24 & $3.96^{*}$ & 0.02 \\
\hline $\begin{array}{l}\text { Looking up } \\
\text { words }\end{array}$ & $2.35(0.76)$ & $2.34(0.74)$ & $2.45(0.88)$ & $2.71(0.79)$ & $2.69(0.78)$ & $2.85(0.81)$ & $21.05^{* * * *}$ & 0.11 & 0.10 & 0.00 \\
\hline $\begin{array}{l}\text { Summarizing } \\
\text { texts }\end{array}$ & $2.44(0.66)$ & $2.42(0.63)$ & $2.55(0.88)$ & $2.80(0.57)$ & $2.76(0.51)$ & $3.10(0.85)$ & $32.55^{* * *}$ & 0.16 & 1.85 & 0.01 \\
\hline $\begin{array}{l}\text { Structuring } \\
\text { texts }\end{array}$ & $2.54(0.64)$ & $2.54(0.64)$ & $2.55(0.68)$ & $2.92(0.57)$ & $2.88(0.56)$ & $3.20(0.61)$ & $37.28^{* * * *}$ & 0.18 & $3.72^{*}$ & 0.02 \\
\hline $\begin{array}{l}\text { Reproducing } \\
\text { texts with } \\
\text { regard } \\
\text { content }\end{array}$ & $2.22(0.55)$ & $2.20(0.54)$ & $2.35(0.58)$ & $2.72(0.55)$ & $2.67(0.51)$ & $3.15(0.67)$ & $60.15^{* * *}$ & 0.26 & $4.08^{*}$ & 0.02 \\
\hline $\begin{array}{l}\text { Index } \\
\text { reading } \\
\text { competency }\end{array}$ & $2.33(0.43)$ & 2.33 & $2.35(.049)$ & $2.79(0.40)$ & $2.75(0.36)$ & $3.06(0.53)$ & $126.44^{* * * *}$ & 0.43 & $7.68^{* *}$ & 0.04 \\
\hline
\end{tabular}

There were no significant differences between the mean judgments of male and female teachers, but 
significant interaction effects "Sex of child $\times$ Sex of teacher". With respect to the detailed competences in reading fluently, taking details from texts, structuring texts, and reproducing texts, male teachers tended to assess boys' reading competencies even poorer than female teachers did. Effect sizes for interaction effects were small ( $\eta^{2}$ between 0.02 and 0.04 ) (see Table 1 ).

Teachers in general assessed the girls' verbal competencies at the time when entering school as better $(M$ $=2.15, S D=4.44)$ than the boys' competencies $\left(M=2.81, S D=0.52 ; F_{(1,162)}=105.04 ; p<0.001 ; \eta^{2}=0.39 ; 1\right.$ = "Very good" to 5 = "Poor"). There was no significant interaction effect "Sex of child $\times$ Sex of teacher", but male teachers' judgment on children's verbal abilities $(M=2.72, S D=0.50)$ was significantly more unfavorable than female teachers' judgment $\left(M=2.44, S D=0.45 ; F_{(1,162)}=8.45 ; p<0.01 ; \eta^{2}=0.05\right)$. Likewise, the case that a child's reading competencies are not developed age appropriately was rated to occur more often for boys $\left(M=2.93, S D=0.63,1=\right.$ "Very often" to $5=$ "Never") than for girls $\left(M=3.39, S D=0.65 ; F_{(1,166)}=\right.$ 56.29; $\eta^{2}=0.25$ ). There was no significant interaction effect and also no significant difference between male and female teachers with respect to this variable.

\section{Reading Behavior and Reading Motivation}

Results of the $2 \times 2$ ANOVAs showed that teachers assessed the general frequency of reading during leisure time for girls $(M=2.30, S D=0.41)$ to be significantly higher than for boys $(M=3.35, S D=0.54)$. Girls were being rated to read "Often", boys only "From time to time". With respect to their motivation to read girls were rated to read most frequently for entertainment $(M=1.87, S D=0.57)$ and to relax $(M=2.47, S D=0.84)$, boys also for entertainment $(M=2.46, S D=0.75)$, to get information $(M=2.53, S D=0.71)$, or due to influence of their parents $(M=2.55, S D=0.82)$ (see Table 2). Significant inner subject effects could be found: Girls were rated to read more frequently to relax and for entertainment, boys to get information and due to parents' influence. Effects for these differences were middle to large size ( $\eta^{2}$ between 0.07 and 0.53 ) except for "Influence of parents". There were no significant differences between male and female teachers and no interaction effects "Sex of child $\times$ Sex of teacher" (see Table 2).

Table 2

Assessment of Reading Behavior and Reading Motivation

\begin{tabular}{|c|c|c|c|c|c|c|c|c|c|c|}
\hline & $\begin{array}{l}M(S D) \\
\text { girls }\end{array}$ & $\begin{array}{l}M(S D) \\
\text { teachers }\end{array}$ & Female/Male & $\begin{array}{l}M(S D) \\
\text { boys }\end{array}$ & $\begin{array}{l}M(S D) \\
\text { teachers }\end{array}$ & Female/Male & $\begin{array}{l}F \quad \text { (Inner } \\
\text { subject } \\
\text { effect) }\end{array}$ & $\eta^{2}$ & $\begin{array}{l}F \\
\text { (Interaction } \\
\text { sex of } \\
\text { teacher } \times \\
\text { Sex of child) }\end{array}$ & $\eta^{2}$ \\
\hline $\begin{array}{l}\text { General } \\
\text { frequency of } \\
\text { reading } \\
\text { during leisure } \\
\text { time }\end{array}$ & $\begin{array}{l}2.30^{1} \\
(0.41)\end{array}$ & $2.30(0.47)$ & 2.25 & $3.35(0.54)$ & $3.34(0.52)$ & $3.40(0.59)$ & $183.78^{* * *}$ & 0.53 & 0.50 & 0.00 \\
\hline To relax & $\begin{array}{l}2.47 \\
(0.84)\end{array}$ & $2.43(0.84)$ & $2.70(0.86)$ & $3.34(0.65)$ & $3.32(0.65)$ & $3.45(0.68)$ & $23.62^{* * *}$ & 0.30 & 0.17 & 0.00 \\
\hline $\begin{array}{l}\text { To get } \\
\text { information }\end{array}$ & $\begin{array}{l}2.92 \\
(0.59)\end{array}$ & $2.92(0.56)$ & $2.90(0.78)$ & $2.53(0.71)$ & $2.52(0.69)$ & $2.60(0.82)$ & $12.21^{* *}$ & 0.07 & 0.27 & 0.00 \\
\hline $\begin{array}{l}\text { For } \\
\text { entertainment }\end{array}$ & $\begin{array}{l}1.87 \\
(0.57)\end{array}$ & $1.87(0.55)$ & 1.90 & $2.46(0.75)$ & $2.46(0.72)$ & $2.45(0.94)$ & $28.29^{* * * *}$ & 0.14 & 0.03 & 0.00 \\
\hline $\begin{array}{ll}\text { Due } & \text { to } \\
\text { parents' } & \\
\text { influence } & \end{array}$ & $\begin{array}{l}2.84 \\
(0.74)\end{array}$ & $2.81(0.74)$ & 3.05 & $2.55(0.82)$ & $2.50(0.79)$ & $2.90(1.02)$ & $4.89^{*}$ & 0.02 & 0.58 & 0.00 \\
\hline
\end{tabular}




\section{Reading Interest}

Fitting to the results in the field of reading motivation male and female teachers judged girls' general interest in reading to be "Good" ( $M=2.23, S D=0.52)$, boys' only "Satisfactory" $(M=3.28, S D=0.58)$ — difference which was significant $\left(F_{(1,164)}=152.52 ; p<0.001 ; \eta^{2}=0.48\right)$.

Teachers assumed that boys prefer comics $(M=2.02, S D=0.61)$, followed by adventure stories $(M=$ 2.14, $S D=0.63)$ and non-fiction books $(M=2.60, S D=0.77)$ whereas girls were judged to prefer fiction books $(M=2.32, S D=0.84)$, followed by adventure stories $(M=2.46, S D=0.69)$. Significant inner subject effects on these items showed, that teachers assessed boys' interest in comics and non-fiction books to be higher than girls', girls' interest in fiction books to be higher than boys'. No differences were seen with regard to boys' and girls' interest in magazines and adventure stories. No significant differences between male and female teachers could be shown. There was a significant interaction effect "Sex of child $\times$ Sex of teacher" with respect to interest for adventure stories: Female teachers assessed boys' interest in adventure stories to be higher than girls' whilst male teachers saw slightly more interest for girls (see Table 3).

Table 3

Assessment of Reading Interest and Interest in Text Types

\begin{tabular}{|c|c|c|c|c|c|c|c|c|c|c|}
\hline & $\begin{array}{l}M(S D) \\
\text { girls }\end{array}$ & $\begin{array}{l}M(S D) \\
\text { teachers }\end{array}$ & Female/Male & $\begin{array}{l}M(S D) \\
\text { boys }\end{array}$ & $\begin{array}{l}M(S D) \\
\text { teachers }\end{array}$ & Female/Male & $\begin{array}{l}F \text { (Inner } \\
\text { e subject } \\
\text { effect) }\end{array}$ & $\eta^{2}$ & $\begin{array}{l}F \\
\text { (Interaction } \\
\text { sex of child } \\
\times \text { Sex of } \\
\text { teacher) } \\
\end{array}$ & $\eta^{2}$ \\
\hline $\begin{array}{l}\text { Reading } \\
\text { interest }\end{array}$ & $2.23^{1}(0.52)$ & 2.24 & $2.20(0.61)$ & $3.28(0.58)$ & $3.28(0.59)$ & 3.25 & $152.52^{* * *}$ & 0.48 & 0.00 & 0.00 \\
\hline Magazines & $2.75^{2}(0.82)$ & $2.73(0.79)$ & $2.90(1.02)$ & $2.82(0.80)$ & $2.79(0.77)$ & 3.05 & 0.94 & 0.00 & 0.17 & 0.00 \\
\hline Comics & $3.33^{2}(0.64)$ & $3.34(0.61)$ & $3.20(0.83)$ & $2.02(0.61)$ & $2.01(0.59)$ & 2.15 & $157.84^{* * *}$ & 0.48 & 2.26 & 0.01 \\
\hline $\begin{array}{l}\text { Non-fiction } \\
\text { books/texts }\end{array}$ & $3.42^{2}(0.69)$ & $3.44(0.66)$ & 3.25 (0.91) & $2.60(0.77)$ & $2.59(0.77)$ & 2.65 & $54.70^{* * *}$ & 0.24 & 1.65 & 0.01 \\
\hline $\begin{array}{l}\text { Adventure } \\
\text { stories }\end{array}$ & $2.46^{2}(0.69)$ & $2.48(0.66)$ & $2.35(0.87)$ & $2.14(0.63)$ & $2.09(0.59)$ & 2.50 & 1.37 & 0.00 & $7.21^{*}$ & 0.04 \\
\hline $\begin{array}{l}\text { Fiction } \\
\text { books/texts }\end{array}$ & $2.32^{2}(0.84)$ & $2.29(0.81)$ & 2.58 (1.01) & $2.75(0.87)$ & $2.73(0.85)$ & 2.84 & $5.43^{*}$ & 0.03 & 0.34 & 0.00 \\
\hline
\end{tabular}

With respect to content, boys were judged to read “Often” about sports ( $M=1.99, S D=0.57$ ), significantly more frequently than girls, and girls were judged to prefer to read about friendship ( $M=1.63, S D=0.61$ ), love $(M=1.99, S D=0.78)$, and animals $(M=2.01, S D=0.74)$. Interest in reading about history was assessed not to be very high for both boys $(M=3.11, S D=0.86)$ and girls $(M=3.64, S D=0.75)$, but boys' interest was judged to be significantly higher than girls'. For the topic "friendship" there was a significant main effect for sex of teacher: Female teachers $(M=2.29, S D=0.71)$ attributed more general interest in reading on this topic to their pupils than male teachers $(M=2.67, S D=0.86) \operatorname{did}\left(F_{(1,167)}=7.40, p<0.05, \eta^{2}=0.04\right)$. There were significant interaction effects for the topics "animals/nature” and "love”. Male teachers judged boys' interest in reading about animals even lower and girls' even higher than female teachers did and concerning the topic of love, female teachers assessed girls' interest even to be higher and boys' to be lower than male teachers did (see Table 4). 
Table 4

Assessment of Reading Interest With Respect to Topics/Contents

\begin{tabular}{|c|c|c|c|c|c|c|c|c|c|c|}
\hline & $M(S D)$ girls & $\begin{array}{l}M \quad(S D) \\
\text { teachers }\end{array}$ & Female/Male & $\begin{array}{l}M \\
\text { boys }\end{array}$ & $\begin{array}{l}M \quad(S D) \\
\text { teachers }\end{array}$ & Female/Male & $\begin{array}{l}F \text { (Inner } \\
\text { subject } \\
\text { effect) }\end{array}$ & $\eta^{2}$ & $\begin{array}{l}F \\
\text { (Interaction } \\
\text { sex of child } \\
\times \text { Sex of } \\
\text { teacher) }\end{array}$ & $\eta^{2}$ \\
\hline Sports & $3.50^{1}(0.70)$ & $3.60(0.68)$ & $3.50(0.82)$ & $1.99(0.57)$ & $1.99(0.52)$ & $1.95(0.88)$ & $221.60^{* * * *}$ & 0.56 & 0.07 & 0.00 \\
\hline $\begin{array}{l}\text { Animals } \\
\text { nature }\end{array}$ & $2.01(0.74)$ & $2.07(0.74)$ & $1.60(0.68)$ & $2.60(0.81)$ & $2.58(0.80)$ & 2.75 & $52.52^{* * * *}$ & 0.23 & $7.58^{*}$ & 0.04 \\
\hline Love & $1.99(0.78)$ & $1.95(0.75)$ & $2.30(0.97)$ & $4.12(0.69)$ & $4.16(0.66)$ & 3.85 & $251.31^{* * *}$ & 0.60 & $7.83^{*}$ & 0.04 \\
\hline Friendship & $1.63(0.61)$ & $1.59(0.58)$ & $1.90(0.78)$ & $3.05(0.90)$ & $3.00(0.88)$ & 3.45 & $158.24^{* * *}$ & 0.48 & 0.35 & 0.00 \\
\hline $\begin{array}{l}\text { Ancient } \\
\text { times } \\
\text { history }\end{array}$ & $3.64(0.75)$ & $3.63(0.73)$ & $3.70(0.86)$ & $3.11(0.86)$ & $3.13(0.84)$ & 3.00 & $29.31^{* * *}$ & 0.14 & 0.78 & 0.00 \\
\hline
\end{tabular}

\section{Texts Used by Teachers in Literacy Instruction}

Male as well as female teachers preferred non-fiction texts (used "Often") for their literacy instruction, followed by fictional texts and adventure stories. Comics and magazines were used "From time to time" or "Rarely" (see Table 5). There were no significant differences between male and female teachers in the frequency of using certain text genres.

\section{Detrimental Effects on Reading Competencies}

Teachers saw the main reason for low reading competencies for both boys and girls in non-reading parents, high amounts of TV-watching and spending a lot of time with the computer. Migration background, parents' low status, and friends who do not read were judged to have a middle ranged detrimental influence on reading, whilst influences of the fact that both parents are working or growing up with only one parent were assessed to be weak.

Table 5

Frequency of Using Text Types in Classes

\begin{tabular}{llrl}
\hline & Sex of teacher & $n$ & $M(S D)$ \\
\hline \multirow{2}{*}{ Magazines } & Male & 20 & $3.50^{1}(0.76)$ \\
& Female & 149 & $3.56(0.80)$ \\
Comics & Male & 20 & $3.60(0.68)$ \\
& Female & 148 & $3.51(0.78)$ \\
Non-fiction texts & Male & 20 & $2.15(0.93)$ \\
& Female & 149 & $1.94(0.59)$ \\
Adventure stories & Male & 20 & $2.35(0.60)$ \\
\multirow{2}{*}{ Fictional texts } & Female & 147 & $2.41(0.57)$ \\
& Male & 20 & $2.45(0.60)$ \\
\hline
\end{tabular}

Note. $^{1} 1$ = "Very often", 2 = "Often”, 3 = "From time to time", 4 = "Rarely", 5 = "Never".

The $2 \times 2$ ANOVAs revealed significant inner-subject effects which showed that teachers assume that boys' reading competencies are more afflicted than girls' by spending a lot of time with television or computer, by friends who are not interested in reading and by growing up with only one parent. No significant differences between male and female teachers or interaction effects could be shown (see Table 6). 
Table 6

Assessment of Detrimental Influences on Children's Reading Competencies

\begin{tabular}{lllcl}
\hline & $M(S D)$ girls & $M(S D)$ boys & $F$ (inner subject effect) & $\eta^{2}$ \\
\hline Low social status of parents & $2.38^{1}(0.91)$ & $2.36(0.86)$ & 0.27 & 0.00 \\
Migration background & $2.20(0.85)$ & $2.13(0.80)$ & 0.91 & 0.00 \\
Growing up with only one parent & $3.69(0.83)$ & $3.26(0.94)$ & $23.05^{* * *}$ & 0.12 \\
Parents both working & $3.29(0.93)$ & $3.18(0.90)$ & 1.87 & 0.01 \\
Parents who do not read & $1.95(0.81)$ & $1.83(0.73)$ & 0.36 & 0.00 \\
Watching excessive amounts of TV & $2.07(0.80)$ & $1.66(0.62)$ & $28.75^{* * *}$ & 0.14 \\
Spending much time with the computer & $2.24(0.86)$ & $1.74(0.67)$ & $36.28^{* * *}$ & 0.18 \\
Friends who do not read & $2.82(0.83)$ & $2.43(1.07)$ & $10.91^{*}$ & 0.06 \\
\hline
\end{tabular}

Notes. ${ }^{1} 1$ = Very strong, 2 = Strong, 3 = Weak, 4 = Very weak, 5 = Not at all, ${ }^{*} p<0.05,{ }^{* * *} p<0.001$.

\section{Discussion and Conclusions}

Results show that German teachers assume significant gender differences in reading competencies for primary school children, differences which are not consistent with results of empirical studies with German children of that age. Regardless of the detailed competency that had to be assessed, boys' achievement was rated to be lower than girls', and these differences were large—about one $S D$ — with middle to large effect sizes. The same is true for the assessed verbal competencies of girls and boys when entering school and the assessed frequency of the case that a child's reading competencies are not developed age appropriately. In contrast to recent empirical evidence, boys' were rated inferior to girls. Thus the data support the notion that primary school teachers have stereotypical attitudes concerning children's reading competencies in disadvantage of the boys.

With respect to reading behavior (frequency of reading during leisure time) and general interest in reading, teachers' judgments for boys and girls are even more apart, nearly two $S D$ s. In these domains teachers' perceptions are consistent with results of empirical studies, even though the rating differences seem to be rather large, assessing boys' reading only "From time to time" or "Rarely" and their general reading interest as not quite "Satisfactory". Results of PIRLS 2006 show that whilst 28\% of the German boys never read books or magazines in their leisure time only $11.2 \%$ of the girls never read, but on the other hand $40.6 \%$ of the boys read up to one hour every day and 30.9\% more than one hour (Bos et al., 2007).

Looking at text types and contents that teachers assume boys and girls to prefer, they seem to be rather gender stereotypical but, at least partly, to be consistent with results of recent studies. Nevertheless, a striking fact is that there is only a small correspondence of teachers' hypotheses on reading preferences with the types of texts teachers use in their literacy lessons. Teachers most frequently use non-fiction texts and rarely use comics in spite of their judgment that girls prefer fiction books and boys prefer adventure stories and comics.

Teachers' judgments on possible influences on children's reading competencies are also rather consistent with results of recent studies. Baier and Pfeiffer (2011) showed that spending large amounts of time watching TV and playing computer games are the two most detrimental influences on primary school boys' general achievement at school and studies like PIRLS reveals a migration background and low status of parents as significant negative influences on children's reading abilities in general (Bos et al., 2008).

When we take a look at differences between male and female teachers' judgments nearly no general differences in the form of main effects can be found. Male teachers seem to have more negative attitudes 
towards children's general verbal abilities at the age when they enter school. But the interaction effects "Sex of child $\times$ Sex of teacher" in the field of reading competencies show that male teachers believe these differences to be greater than female teachers do. A look at the means of male and female teachers on the built "Index reading competency", the mean of the judgments of all detailed competencies, shows that these effects mainly result from male teachers assessing boys' competencies even lower than female teachers do.

With respect to teachers' attitudes on gender differences in preferred text types, interaction effects point out greater stereotypes in female teachers with respect to some items as well as for male teachers when looking at other ones. Male teachers see greater differences in interest for stories about animals and nature than female teachers do, whilst female teachers see a greater gender difference in interest for love stories and adventure books.

As a general consequence of these results it seems necessary to analyze and discuss the possible influences of teachers' stereotypical and non-realistic perceptions of boys' reading competencies on boys' reading self-concepts and reading motivation. One could assume similar effects as it has been shown for teachers' negative stereotypes on girls' competencies in mathematics, like lower self-concept in reading and/or creating situations of stereotype threat, which has detrimental effects on reading achievement. Actually, recent studies (Bos et al., 2008; Möller \& Bonerad, 2007) show no gender differences in reading self-concept for younger children and first studies on effects of stereotype threat for the reading achievement of secondary school boys (Eckert \& Imhof, 2012) even found an enhancement of boys' reading achievement under the condition of stereotype threat. Schirner (in press) found no differences with respect to gender specific classroom interactions in lessons in reading and language for primary school children between teachers with and without stereotypes in disadvantage of the boys for this subject. Thus it might be promising to study the consequences of teachers' stereotypes on boys' reading motivation. As Deci and Ryan (1985) pointed out intrinsic motivation is enhanced by a feeling of competence and autonomy. Maybe boys' lack of intrinsic motivation to read, which is blamed as one of the main causes for boys' inferior readings competencies in secondary school, is a result of a combination of negative feedback on their reading competency and a lack of autonomy, e.g., to choose reading materials on their own.

Interaction effects "Sex of child $\times$ Sex of teacher" have to be discussed with respect to the discourse on "Feminization of teaching" as a cause of boys failing at school. The fact that male primary school teachers seem to judge boys' competencies even poorer than their female colleagues do is inconsistent with the notion that the overweight of female primary school teachers discriminates boys by giving them bad marks and thus might be responsible for boys falling back behind girls at school.

Of course, this study has some limitations that affect the generalizability of the findings. The sample is too small and with respect to age not representative for the population of primary school teachers as a whole. The former, due to the small quota of male primary school teachers, is especially true for the subsample of male teachers. Thus, also with regard to the small effect sizes, the results on gender specific interaction effects have to be interpreted with caution and must be verified by a larger sample.

\section{References}

Baier, D., \& Pfeiffer, Ch. (2011). Mediennutzung als Ursache für schlechtere Schulleistungen von Jungen (Media consume as a cause for boys' failing at school). In A. Hadjar (Ed.), Geschlechtsspezifische Bildungsungleichheiten (Gender specific inequalities in education) (pp. 261-284). Wiesbaden: VS Verlag für Sozialwissenschaften. 
BfFSFJ (Bundesministerium für Familie, Senioren, Frauen und Jugend). (2007). Mädchen und Jungen in Deutschland. Lebenssituationen-Unterschiede-Gemeinsamkeiten (Girls and boys in Germany: Life situation—differences-similarities). Berlin.

Birkenbihl, F. (2005). Jungen und Mädchen: Wie sie lernen (Boys and girls: How they learn). München: Knaur.

Blossfeld, H. P., Bos, W., Hannover, B., Lenzen, D., Müller-Böling, D., Prenzel, M., \& Wößmann, L. (Hrsg.). (2009). Aktionsrat Bildung. Geschlechterdifferenzen im Bildungssystem: Jahresgutachten 2009 (Gender differences in the educational system: Report 2009). Verlag für Sozialwissenschaften.

Bos, W., Bonsen, M., Baumert, J. Prenzel, M., Selter, Ch., \& Walther, G. (Hrsg.) (2008). Mathematische und naturwissenschaftliche Kompetenzen von Grundschulkindern in Deutschland im internationalen Vergleich (German primary school children's competencies in mathematics and science in international comparison). Münster: Waxmann.

Bos, W., Hornberg, S., Arnold, K. H., Faust, G., Fried, L., Lankes, E. M., Schwippert, K., \& Valtin, R. (Hrsg.). (2007). IGLU 2006: Lesekompetenzen von Grundschulkindern in Deutschland im internationalen Vergleich (IGLU 2006: German primary school children's reading competencies in international comparison). Münster: Waxmann.

Bos, W., Hornberg, S., Arnold, K. H., Faust, G., Fried, L., Lankes, E. M., Schweippert, K., Veltin, M. (Hrsg.). (2008). IGLU-E 2006: Die Länder der Bundesrepublik Deutschland im nationalen und internationalen Vergleich (IGLU-E 2006: The German federal states in national and international comparison). Münster: Waxmann.

Budde, J. (2008). Bildungs(miss)erfolge von Jungen und Berufswahlverhalten bei jungen/männlichen Jugendlichen (Boys' failures in the educational system and occupational choices of male adolescents). BMBF: Bonn, Berlin, Bildungsforschung Band 23.

Bühner, M. (2011). Einführung in die Test und Fragebogenkonstruktion (Introduction in test and questionnaire construction). München: Pearson.

Carrington, B., Tymms, P., \& Merrell, Ch. (2008). Role models, school improvement and the "gender gap"-Do men bring out the best in boys and women the best in girls? British Educational Research Journal, 34, 315-327.

Deci, E. L., \& Ryan, R. M. (1985). Intrinsic motivation and self-determination in human behavior. New York: Plenum.

Eckert, C., \& Imhof, M. (2011). Müssen Jungen zu guten Leseleistungen herausgefordert werden? (Do boys have to be challenged to do better in reading?). Vortrag auf der 13. Fachgruppentagung Pädagogische Psychologie der DGPs (Oral presentation at the 13th conference of the section educational psychology of the DGPS), Erfurt, September 14-16, 2011.

Eckert, C., \& Imhof, M. (2012). Leseleistung = Schulform + Domain Identification + Situation + Geschlecht? (Reading achievement $=$ type of school + domain identification + situation + sex?) Vortrag auf dem 48. Kongress der DGfP (Oral presentation at the 48th conference of the German Association for Psychology), Bielefeld, September 23-27, 2012.

Endepohls-Ulpe, M. (2011). Ist Mädchenförderung weiterhin notwendig? Zur Situation von Mädchen und Jungen im Bildungssystem (Is promotion of girls still necessary?). In C. Quaiser-Pohl, E. Sander, \& M. Endepohls-Ulpe (Hrsg.), Ada Lovelace Schriftenreihe (Ada Lovelace Series), 17, 6-30. Koblenz: Universität Koblenz-Landau.

Endepohls-Ulpe, M. (2012). Are females or males disadvantaged in contemporary educational systems? In C. Quaiser-Pohl, \& M. Endepohls-Ulpe (Eds.), Women's choices in Europe: Influence on education, occupational career and family development (pp. 15-28). Münster: Waxmann.

Engelhardt, K. (2006). Jungen lesen?! Methoden jungenspezifischer Leseförderung. Entwicklung eines Konzepts zur Fortbildung von Bibliothekaren, Lehrern, Erziehern und Eltern (Boys read? Methods of boy-specific furthering of reading competencies. Development of an advanced training for librarians, teachers, kindergarten teachers and parents). Diplomarbeit Studiengang Bibliotheks—und Medienmanagement Fachhochschule Stuttgart-Hochschule der Medien: Stuttgart (Diploma thesis, degree program library and media management, Unversity of Applied Sciences Stuttgart). Retrieved October 12, 2012, from http://www.hdm-stuttgart.de/ifak/publikationen/abschlussarbeiten/ifakabschlussarbeit20070605143756/DA_Engelhardt.pdf

Gilbert, R. (2009). Teaching and the boy problem. In L. J. Saha, \& A. G. Dwarkin (Eds.), International handbook of research on teachers and teaching (pp. 929-937). New York: Springer.

Hadjar, A. (Ed.) (2011). Geschlechtsspezifische Bildungsungleichheiten (Gender specific inequalities in education) (pp. 393-416). Wiesbaden: VS Verlag für Sozialwissenschaften.

Hannover, B. (2004). Gender revisited: Konsequenzen aus PISA für die Geschlechterforschung (Consequences from PISA for gender research). Zeitschrift für Erziehungswissenschaft, 7(3), 81-99.

Hannover, B., \& Kessels, U. (2011). Sind Jungen die neuen Bildungsverlierer? Empirische Evidenz für Geschlechterdisparitäten zuungunsten von Jungen und Erklärungsansätze (Are boys left behind at school? Reviewing and explaining education-related gender disparities). Zeitschrift für Pädagogische Psychologie, 25(2), 89-103. doi 10.1024/1010-0652/a000039. 
Helbig, M. (2012). Sind Mädchen besser? Der Wandel geschlechtsspezifischen Bildungserfolgs in Deutschland (Are girls better? The change of gender specific educational success in Germany). Frankfurt: Campus.

Herwartz-Emden, L., Braun, C., Heinze, A., Rudolph-Albert, F., \& Reiss, K. (2008). Geschlechtsspezifische Leistungsentwicklung von Kindern mit und ohne Migrations-hintergrund im frühen Grundschulalter (Gender-specific development of children's achievement with and without migration background). Zeitschrift für Grundschulforschung. Bildung im Elementar-und Primarbereich, 2, 13-28.

Kölbl, C., Tiedemann, J., \& Billmann-Mahecha, E. (2006). Die Bedeutung der Lesekompetenz für die Sachfächer (The impact of reading competency for the subject social studies). Psychologie in Erziehung und Unterricht, 53, 201-212.

Lingard, B. (2003). Where to in gender policy in education after recuperative masculinity politics? International Journal of Inclusive Education, 7, 33-56.

Mills, M. (2003). Shaping the boys’ agenda: The backlash blockbusters. International Journal of Inclusive Education, 7, 57-73.

Möller, J., \& Bonerad, E. M. (2007). Fragebogen zur habituellen Lesemotivation (Questionnaire on habitual reading motivation). Psychologie in Erziehung und Unterricht, 54, 259-267.

Mullis, I. V. S., Martin, M. O., Kennedy, A. M., \& Foy, P. (2007). PIRLS 2006 international report: IEA's progress in international reading literacy study in primary school in 40 countries. Chestnut Hill, M. A.: TIMSS \& PIRLS International Study Center, Boston College.

Naumann, J., Artelt, C., Schneider, W., \& Stanat, P. (2010). Lesekompetenz von PISA 2000 bis PISA 2009 (Reading competencies from PISA 2000 to PISA 2009). In E. Klieme, C. Artelt, J. Hartig, N. Jude, O. Köller, M. Prenzel, W. Schneider, \& P. Stanat (Eds.), PISA 2009: Bilanz nach einem Jahrzehnt (PISA 2009: Report after one decade) (pp. 23-72). Münster: Waxmann.

Neuburger, S., Jansen, P., Heil, M., \& Quaiser-Pohl, C. (2012). A threat in the classroom: Gender stereotype activation and mental-rotation performance in elementary-school children. Journal of Psychology, 220, 61-69. doi: 10.1027/2151-2604/a000097.

Neugebauer, M. (2011). Werden Jungen von Lehrerinnen bei den Übergangsempfehlungen für das Gymnasium benachteiligt? Eine Analyse auf Basis der IGLU-Daten (Are boys discriminated by female teachers concerning their recommendations to attend a Gymnasium?). In A. Hadjar (Ed.), Geschlechtsspezifische Bildungsungleichheiten (Gender specific inequalities in education) (pp. 235-260). Wiesbaden: VS Verlag für Sozialwissenschaften.

Philipp, M., \& Garbe, C. (2007). Lesen und Geschlecht-Empirisch feststellbare Achsen der Differenz (Reading and gender-Empirically determinable axes of difference). In A. Bertschi-Kaufmann (Hrsg.), Lesekompetenz, Leseleistung, Leseförderung, Grundlagen, Modelle und Materialien (Reading competency, reading achievement, reading promotion, basic principles, models and materials)(CD-Beilage). Zug: Klett und Balmer Verlag.

Prenzel, M., Baumert, J., Blum, W., Lehmann, R., Leutner, D., Neubrand, ... Schiefele, U. (Hrsg.). (2004). PISA 2003: Der Bildungsstand der Jugendlichen in Deutschland-Ergebnisse des zweiten internationalen Vergleichs (PISA 2003: Educational background of German adolescents-Results of the second international comparison). Münster: Waxmann.

Richter, K., \& Plath, M. (2007). Lesemotivation in der Grundschule: Empirische Befunde und Modelle für den Unterricht (Reading motivation in primary school: Empirical results and models for instruction). Weinheim und München: Juventa Verlag.

Riedinger, A. (2011). Brauchen Jungen im Grundschulalter Leseförderung? Lesemotivation, Leseselbstkonzept und Leseinteresse von Grundschulkindern aus Schüler- und Lehrerperspektive (Do primary school boys need reading promotion? Primary school children's reading motivation, reading self-concept and reading interest from children's and teachers' point of view). Unveröffentlichte Masterarbeit, Universität Koblenz-Landau, Fachbereich Bildungswissenschaften.

Rohe, A., \& Quaiser-Pohl, C. (2010). Prädiktoren für mathematische Kompetenzen zu Beginn der Grundschule-Gibt es Unterschiede zwischen Jungen und Mädchen (Predictors of mathematical competencies at the beginning of primary school—Are there differences between boys and girls?). In C. Quaiser-Pohl, \& M. Endepohls-Ulpe, Bildungsprozesse im MINT-Bereich (Educational processes in the field of STEM) (S. 13-27). Münster: Waxmann.

Rohrmann, T. (2007). Lernen Jungen ander(e)s als Mädchen? Zusammenhänge von Bildung und Geschlecht (Boys and girls_Learning differently and/or different things? Interrelations of education and gender). In A. Neider (Ed.), Brauchen Jungen einer andere Erziehung als Mädchen (Do boys need a different education than girls?) (pp. 11-41). Stuttgart: Verlag Freies Geistesleben. 
Rustemeyer, R., \& Jubel, A. (1996). Geschlechtsspezifische Unterschiede im Unterrichtsfach Mathematik hinsichtlich der Fähigkeitseinschätzung, Leistungserwartung, Attribution sowie im Lernaufwand und im Interesse (Gender differences in pupils' assessment of their abilities, expectation of their achievement, their attribution, as well as learning efforts and interest in mathematics). Zeitschrift für Pädagogische Psychologie, 10, 13-25.

Schirner, S. (in press). Geschlechtsstereotype Interaktionseffekte: Eine Videobasierte Analyse der Schülerbeteiligung (Gender stereotyped interaction effects: A video-based analysis of students' participation). Berlin: Logos.

Smith, E. (2003). Failing boys and moral panics: Perspectives on the underachievement debate. British Journal of Educational Studies, 51, 282-295.

Sokal, L., Katz, H., Chaszewski, L., \& Wojcik, C. (2007). Good-bye, Mr. Chips: Male teacher shortages and boys’ reading achievement. Sex Roles, 56, 651-659.

Spencer, S. J., Steele, C. M., \& Quinn, D. M. (1999). Stereotype threat and women's math performance. Journal of Experimental Social Psychology, 35, 4-28.

Statistisches Bundesamt (Federal Statistical Office). (2012). Schulen auf einen Blick (Schools at a glance). Wiesbaden: Statistisches Bundesamt.

Steele, C. M. (1997). A threat in the air: How stereotypes shape intellectual identity. American Psychologist, 52, 613-629.

Tiedemann, J. (1995). Geschlechtstypische Erwartungen von Lehrkräften im Mathematikunterricht in der Grundschule (Teachers' gender specific expectations in primary school math classes). Zeitschrift für Pädagogische Psychologie, 9, 153-161.

Titus, J. J. (2004). Boy trouble: Rhetorical framing of boys' underachievement. Discourse: Studies in the Cultural Politics of Education, 25, 145-169.

Weaver-Hightower, M. (2003). The "boy-turn” in research on gender and education. Review of Educational Research, 73, 471-498.

Wright, St. C., \& Taylor, D. M. (2003). The social psychology of cultural diversity: Social stereotyping, prejudice, and discrimination. In M. A. Hogg, \& J. Cooper, The SAGE handbook of social psychology (pp. 432-457). London: SAGE Publications.

Ziegler, A., Kuhn, C., \& Heller, K. A. (1998). Implizite Theorien von Gymnasialen Mathematik und Physiklehrkräften zu geschlechtsspezifischer Begabung und Motivation (Implicit theories of German gymnasium teachers on gender specific ability and motivation). Psychologische Beiräge, 40, 271-287. 